OPEN ACCESS

Edited by:

Saket Pande,

Delft University of

Technology, Netherlands

Reviewed by:

Virginia Barros,

Santa Catarina State University, Brazil

Jiahong Liu,

China Institute of Water Resources and Hydropower Research, China

${ }^{*}$ Correspondence:

Yunfei QI

yunfei.qi@nottingham.edu.cn

Faith Ka Shun Chan

faith.chan@nottingham.edu.cn

Emily C. O'Donnell

emily.o'donnel/@nottingham.ac.uk

Meili Feng

meili.feng@nottingham.edu.cn

Yanfang Sang

sangyf@igsnrr.ac.cn

Colin R. Thorne

colin.thorne@nottingham.ac.uk James Griffiths

james.griffiths@niwa.co.nz

Lingyun Liu

tinaliu1990@qq.com

Sitong Liu

liu.sitong@nottingham.edu.cn

Chunqian Zhang

601336518@qq.com

Lei Li

zy13104@nottingham.edu.cn

Dimple Thadani

dimple.thadani@nottingham.edu.cn

Specialty section:

This article was submitted to Water and Human Systems, a section of the journal

Frontiers in Water

Received: 06 March 2021 Accepted: 09 April 2021

Published: 20 May 2021

Citation:

Qi Y, Chan FKS, O'Donnell EC,

Feng $M$, Sang $Y$, Thorne $C R$, Griffiths J, Liu L, Liu S, Zhang C, Li L and Thadani D (2021) Exploring the

Development of the Sponge City Program (SCP): The Case of Gui'an

New District, Southwest China.

Front. Water 3:676965.

doi: 10.3389/frwa.2021.676965

\section{Exploring the Development of the Sponge City Program (SCP): The Case of Gui'an New District, Southwest China}

\author{
Yunfei Qi ${ }^{1,2 *}$, Faith Ka Shun Chan ${ }^{1,3,4 *}$, Emily C. O’Donnell ${ }^{5 *}$, Meili Feng ${ }^{1 *}$, Yanfang Sang ${ }^{6 *}$, \\ Colin R. Thorne ${ }^{5 *}$, James Griffiths ${ }^{7 *}$, Lingyun Liu ${ }^{2 *}$, Sitong Liu ${ }^{1 *}$, Chunqian Zhang ${ }^{2 *}$, \\ Lei $\mathrm{Li}^{1 *}$ and Dimple Thadani ${ }^{8 *}$ \\ ${ }^{1}$ School of Geographical Sciences, University of Nottingham Ningbo, Ningbo, China, ${ }^{2}$ Guizhou Survey \& Design Research \\ Institute for Water Resources and Hydropower, Guiyang, China, ${ }^{3}$ School of Geography, University of Leeds, Leeds, \\ United Kingdom, ${ }^{4}$ Water@Leeds Research Institute, University of Leeds, Leeds, United Kingdom, ${ }^{5}$ School of Geography, \\ University of Nottingham, Nottingham, United Kingdom, ${ }^{6}$ Institute of Geographic Sciences and Natural Resources Research \\ Chinese Academy of Sciences, Beijing, China, ${ }^{7}$ National Institute of Water and Atmospheric Research Ltd (NIWA), \\ Christchurch, New Zealand, ${ }^{8}$ Nottingham University Business School, University of Nottingham Ningbo China, Ningbo, China
}

Rapid urbanization has sharply increased the pressure of urban water issues (e.g., urban flooding and water pollution) in the Chinese megacities during last three decades. Sustainable urban water management approaches, such as Nature Based Solutions (NBS) and Low Impact Developments (LIDs), have successfully delivered long-term benefits to cities in Europe and North America. Similarly, the Chinese Sponge City Program (SCP) initiated in 2013 and experimented in 30 pilot Chinese cities. This paper reviewed the first stage of the SCP from 2015 to 2020 by using observation, Semi-Structured Interview (SSI) and Focus Group Approach (FGA) in context of Gui'an New Distinct, SW China to investigate the SCP progress and issues: (1). whether it is effectively solving urban water issues; (2). if there are any major challenges and barriers in the SCP practice. The findings of this case study provide potential solutions for improving the SCP and sustainable urban water management and possibly transform to other Sponge Cities in China.

Keywords: Sponge City Program, Gui'an New Distinct, Guiyang, urban water management, socio-ecological practices, public perceptions, stakeholder engagement

\section{INTRODUCTION}

The scientific community has a general viewpoint that urban water management issues are more frequent worldwide (Qiao et al., 2020). Many megacities are facing increasing risks of urban flooding, waterlogging, water pollution, and degradation of water-ecological systems (O'Donnell and Thorne, 2020). Rapid urbanization has been occurring in China over the last four decades. From 1980 to 2015, the urban population has increased from 19 to $56.1 \%$ in Chinese cities (Jiang et al., 2018). The urban water issues, particularly urban flood and waterlogging, have become more serious (Chan et al., 2014). In order to improve urban water management, the Chinese National Government have built many hard-engineering infrastructure (e.g., dams, barriers, and walls). More than 97,000 dams were built during the 1950s after WWII (Cheng, 2005); and the main purpose was large energy consumption that was required for substantial hydroelectric generation, 
water supply and flood control (Chan et al., 2018). Unfortunately, only relying on hard-engineering infrastructure enable effective protection from fluvial floods in the upstream catchment areas and address flash floods caused by hillslope processes, but seemingly are not too sufficient for addressing urban flood issues in the low-lying flood prone areas (Zong and Chen, 2000).

As Chinese cities and the economy develop, citizens are now seeking safer and higher quality living environments. Traditional urban water management has shifted to deliver more social and sustainable aspects (Xiang et al., 2019). For example, Guangming New District in Shenzhen has successfully experimented the Low Impact Development (LID) practice in new urban district areas (Lancia et al., 2020). Previous advanced urban developing experience enlightened Chinese Government to deeply improve urban developing strategy (Lashford et al., 2019). After learning from global practices, such as "Sustainable Drainage Systems" (SuDS), "Best Management Practices" (BMPs),"Water Sensitive Urban Design" (WSUD), "Low Impact Urban Design and Development" (LIUDD), "Active Beautiful and Clean Waters" (ABC), "Blue-Green City" (BGC) (O’Donnell et al., 2017), "Low Impact Development" (LID) and "Nature-Based Solutions" (NBS) (Qi et al., 2020), the Chinese began to find their own path toward more sustainable, blue-green urban water management.

The Sponge City Program (SCP) was officially proposed by President Xi Jinping in 2013 (Nguyen et al., 2020). This concept simulates the natural water cycle to address urban water issues and ultimately achieves sustainable urban development (Lashford et al., 2019). In October 2014, the Ministry of Housing and Urban-Rural Development (MHURD) published the "Technical Guidelines for Sponge City Construction" (trial) as the major framework for the SCP (Ministry of Housing UrbanRural Development, 2014). In 2015 and 2016, the National Government, respectively, selected the first batch of 16 cities (e.g., Wuhan, Chongqing, Xiamen, Gui'an New District) and the second batch of 14 cities (e.g., Beijing, Tianjin, Dalian, Shanghai, Ningbo, Shenzhen, Sanya) as the pilot cases under SCP (Lashford et al., 2019).

Gui'an New District is the new developed urban district in Guiyang city circle. It is surrounded by hilly and mountainous topographical features, which means the city lies in the valley and frequently experiences flash floods (Yang et al., 2020). The first stage (2015-2020) of SCP implementation was completed in Gui'an New District. This paper found that the SCP pilot case of Gui'an still had challenges and barriers. For instance, the governance system of the SCP is complex; the coordination within governments, departments and bureaus is difficult ( $\mathrm{Wu}$ et al., 2020). The current SCP is still establishing informative and transparent guidelines that less integrate with local knowledge and conditions (e.g., geography, social-economic, and hydrological patterns) (Griffiths et al., 2020), which potentially present an obstacle to tailor the SCP to specific sponge cities (Zevenbergen et al., 2018). China has a centralized government and people have less chance to participate in policy making and urban planning (Chen and Chen, 2020). The public perception and participation of SCP are still rather not popular at this stage (Yutao et al., 2017; Chan et al., 2020).
This paper aims to minimize the research gaps on the practice of the SCP by exploring the case of Gui'an New District in Guiyang, SW China. The specific objectives of the paper include; (1) exploring and understanding the barriers to current progress of the SCP in Gui' an New District; (2) determining existing issues with governance, standards, planning, design, finance, and public perception by in-depth discussions with stakeholders via SemiStructured Interviews (SSI) and Focus Group Approach (FGA); (3) discussing and providing recommendations for solving the challenges associated with the SCP to deliver a more adaptable and sustainable program.

\section{METHODS}

\section{Case Study-Background}

Gui'an New District was developed in 2011 in southwestern China. It is located in the Guiyang metropolitan area, the eighth national-level new district with planning land area consisting of $1,795 \mathrm{~km}^{2}$ and planned future population of 790,000 (toward to 2030s). Gui'an New District has its own District Government under the governance of Guiyang Municipal Government. The size of the central area of Gui'an New District is about $43.25 \mathrm{~km}^{2}$ (Gui' an Urban Planning Construction Bureau, 2014) (Figure 1). Public infrastructures (e.g., roads and parks), business and residence zones have been built, as have more artificial concrete surfaces (e.g., impermeable roads and squares), and new developments are ongoing. In terms of geography and topographical features, the district is surrounded by hills as a typical mountainous city. Most available land is thus located on low-lying flood prone areas with high risks of flash flood and waterlogging disasters. The development of the new district is doubted under detailed study of flood risk assessment according to the current urban planning (Yang et al., 2020).

As a result, many original natural surfaces (e.g., forest, fields and open grasslands) have been reduced, the urban hydrological process is affected and the soilwater infiltration rate has decreased. The current existing drainage system has the flood protection standard of 1 in 5 years return period, which is unable to handle the peak discharge water during intensive rainfall events, and further urbanization will continually increase the urban flood risk (Chan et al., 2018). In future, if the urban land drainage capacity does not improve the current, inadequate standard, the urban flood risk will keep increasing with the urbanization.

Average annual precipitation is $1,129 \mathrm{~mm}$ in Gui'an New Distinct, ranging from 1,760 (maximum in 1954) to $718 \mathrm{~mm}$ (minimum in 1981). The wet season from April to September delivers abundant rainfall $(886 \mathrm{~mm})$, accounting for about $78.5 \%$ of yearly precipitation (Hydrology Bureau of Guizhou Province, 2015). The highest monthly precipitation is in July with an average of 300-400 mm (Guizhou Meteorological Bureau, 2020). Figure 2 illustrates the average annual precipitation of Gui'an New District; such precipitation pattern also enhances higher potential flash fluvial and urban flood risks.

Gui'an New Distinct was selected in the first batch of pilot sponge cities in 2015 by the National Government (Li et al., 


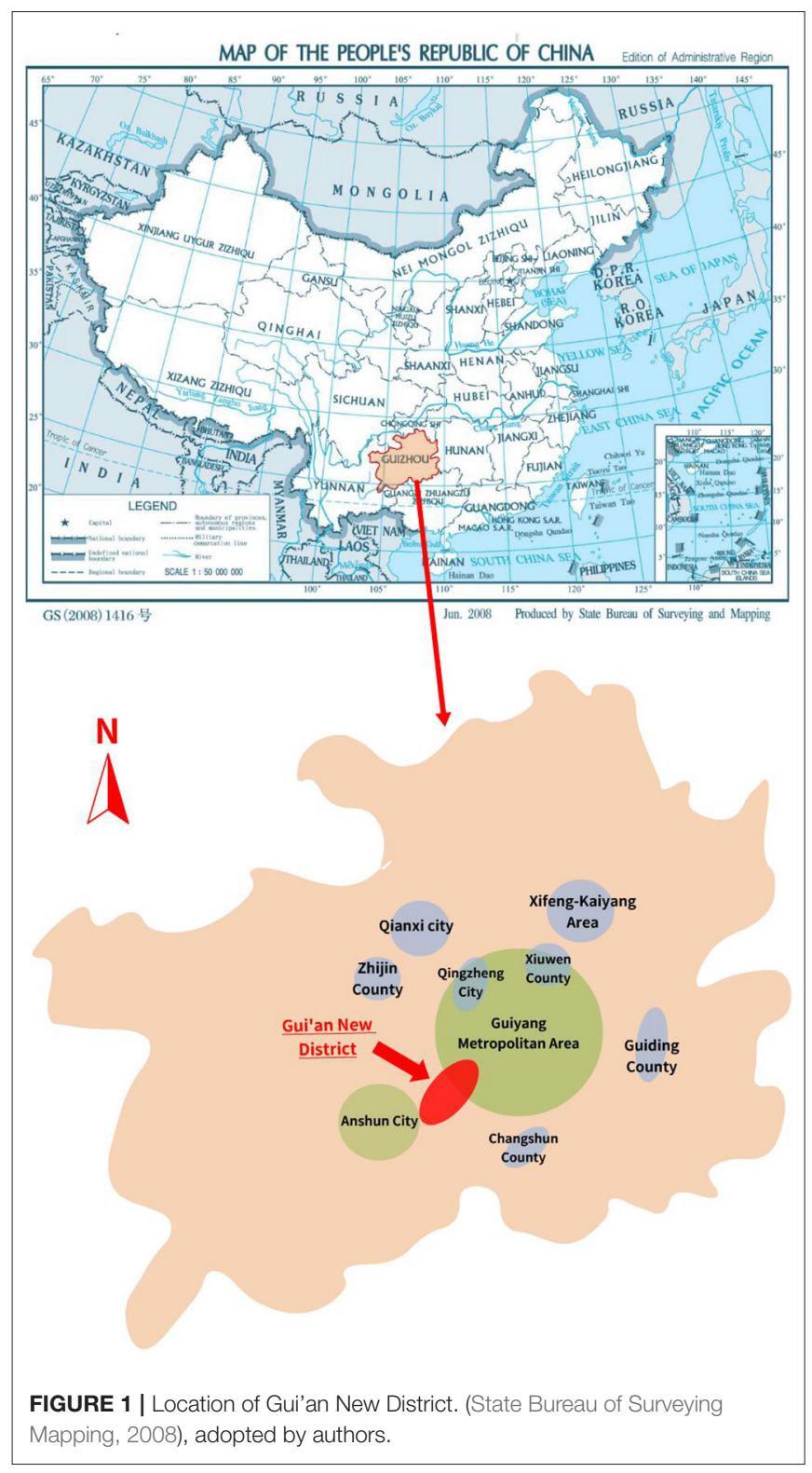

2017). The District Government has invested 4.67 billion yuan (RMB) (about 724 million USD) on SCP from 2015 to 2020 (Yang et al., 2020). According to the "Technical Guidelines for Sponge City Construction (trial)" (The guideline was initially purposed for pilot sponge cities and further applied to all Chinese cities. It was focus on urban areas rather than inartificialnatural watershed characteristics.) and "Sponge City Construction Special Planning for Central Area of Guian New District (2016 2030)," the planned procedure for SCP development in Gui'an New District are summarized as follows: (1) the key objective is to mitigate urban flood and waterlogging issues by using the SCP measures (e.g., permeable road and sunken garden); (2) restoring the natural hydrological processes to mitigate urban water pollution through SCP measures (e.g., natural-purification wetland park); (3) reducing the total annual surface runoff rate to $20-25 \%$ in urban areas by 2030; (4) and finally to achieve multiple social-economic benefits such as improving social well-being and urban eco-system services (Ministry of Housing Urban-Rural Development, 2014; Yang et al., 2020).

From 2015 to 2018, Gui'an New District has implemented the three-level SCP construction according to Gui'an urban planning (Yang et al., 2020). This includes the Micro System (Building System), Medium System (Community System) and Macro System (Urban System). These three systems are complementary with each other to sequentially absorb rainfall (Wang et al., 2018) (See Figure 3). In the Micro System (Building System), green buildings focus on water source control via reducing runoff. For example, green roofs and rooftop gardens can absorb rainwater in mild rainfall events. In moderate rainfall events, the excessive rainwater that green buildings cannot store will be transferred to the Medium System (Community System).

Community green facilities (e.g., rain gardens and sunken lawns) can strengthening and increasing the water retention time to further reduce urban surface water runoff. In intensive rainfall conditions, the rainwater overflows into the Macro System (Urban System). Some green infrastructures (e.g., Wetland Parks) provide flood-buffering zones to reduce urban flood risk. The SCP Guideline requires the pilot cities to achieve the flood protection standard for 1-in-30 year return period events (Chan et al., 2018), vs. the present standard of 1-in-5 year return period. However, the green infrastructures are less effective when the rainfall intensity is more than 1-in-30-years return period. If particular sponge cities do not purposely increase the urban flood protection standard of the SCP, the sponge cities might still need to rely on the gray infrastructures (e.g., flood channel, flood wall, and reservoir) to handle intensive rainstorms (Li et al., 2020).

\section{Semi-structured Interview and Focus Group Approach}

Gui'an New District was selected for the following reasons. (1) Gui'an New District is a first-batch sponge city nominated by the Chinese National Government in 2015 and the local government has implemented pilot SCP projects. (2) Gui'an New District as mentioned that established in 2011 and represents how to implement the SCP in a newly constructed city. (3) Gui'an New District is located in mountainous geography. The issues faced by Gui'an New District commonly inspire other mountainous sponge cities such as Chongqing and Kunming in southwestern China. This case study represents a typical urban water management approach in pilot sponge cities. The experience from 30 pilot sponge cities across China helps decision makers to understand if the implemented SCP is addressing (or failing to address) urban water issues (Xia et al., 2017).

We examine the challenges and barriers in SCP governance, standards, planning, design, finance and public perception and developing strategies to deliver a better SCP. The interview 


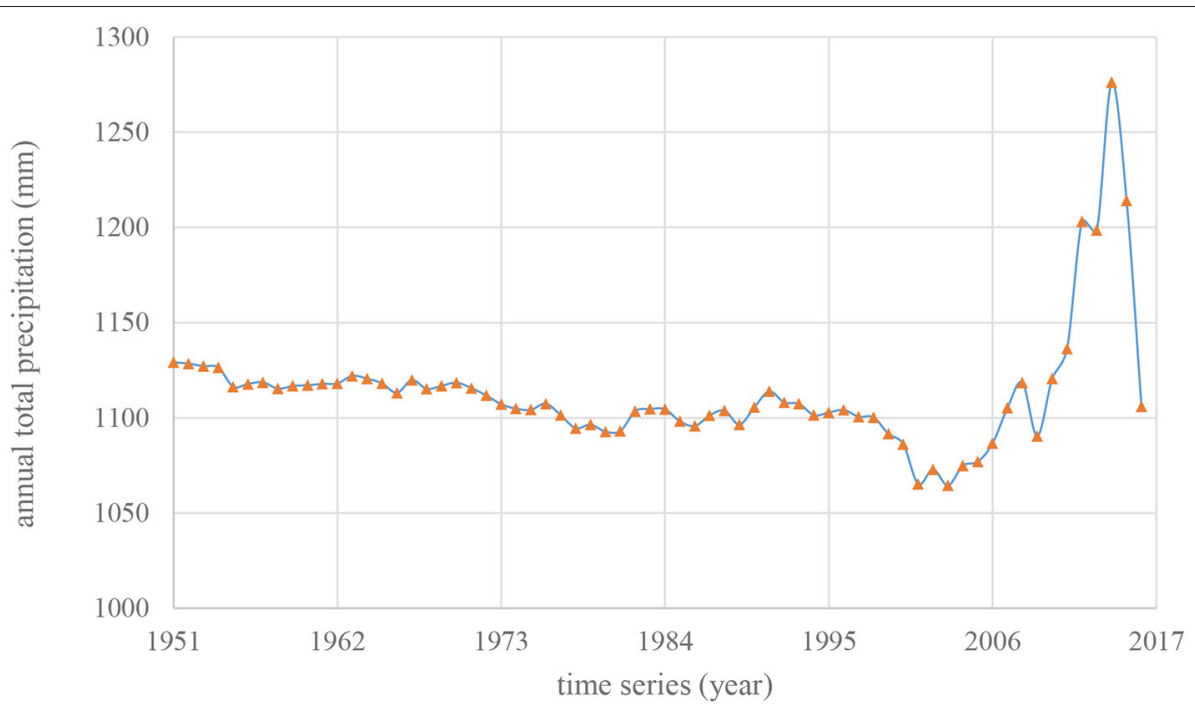

FIGURE 2 | Annual Total Precipitation (Guizhou Meteorological Bureau, 2020), adapted by the authors.



FIGURE 3 | The SCP technical system (Source: authors).

methods usually include Structured Interview (SI), SemiStructured Interview (SSI), Unstructured Interview (UI), and Focus Group Approach (FGA) (Bjørnholt and Farstad, 2012; Edwards and Holland, 2013). These methods are widely used in social science. SI is an interview method with a totally planned and a rigorous set of questions, which means all interviewees get the same questions. On the opposite of SI, UI tends to be more informal, which makes it more like a daily communication (Bjørnholt and Farstad, 2012). Comparing with SI and UI, SSI has an sketch guideline for topics allowing 
interviewees express new ideas as results (Bolderston, 2012). SSI can create an open and relaxed environment for interviewees, which is suitable for collecting deep perspectives of sensitive stakeholders such as government officials, businessmen, and engineers (Galletta and Cross, 2013). FGA is widely used with people who have less sensitive identities (e.g., residents) and know each other (Catherine et al., 2019). FGA can stimulate interviewees to give ideas in guided topics prepared in advance by the interviewer (Qu and Dumay, 2011). SSI and FGA are both communication methods in partially structured, orderly and self-conscious ways (Onwuegbuzie et al., 2009). Both methods are effective in investigating complex opinions, emotions and behaviors, which helps researchers get open feedbacks from respondents.

Semi-Structured Interview (SSI) and Focus Group Approach (FGA) are adopted in this study. In total, there were 26 participants. Sixteen professional stakeholders (Respondent A to $\mathrm{P})$ were invited to participate in individual SSI. They included government and bureau officials, housing developers and sales representatives, bankers, NGO workers, academics, and engineers (Table 1). Their experiences and ideas partly represent the developing conditions of SCP in Gui'an New District. We also invited ten residents (Respondent a to $\mathrm{j}$ ) to participate in a focus group. The FGA included old generation residents (who have been living in the region for more than 30 years) and new citizens (who moved to Gui'an New Distinct during the last 10 years) and explored their historical viewpoints, local knowledge and living experience. Due to the limitations of interviewees' background, experience, knowledge, and willingness, we chose suitable and most frequently occurring topics for different interviewees (Table 1).

Each interview or group meeting took between 30 and $60 \mathrm{~min}$ and were conducted face-to-face, using social media (via WeChat-popular social media platform in China) or by phone call. An ethical process was approved to conduct this research and all data is treated as confidential. All interviewees consented to participate in this research. All interviews were conducted in Mandarin. According to a literature mining for SCP (Zongmin et al., 2018), we prepared most frequently occurring themes as interview topics in SSI and FGA (see Table 1). Meanwhile, the interviews were not strictly limited by the interview guideline. We expended more themes to collect useful information while interviewing participators according to various backgrounds and knowledge of interviewees (actors in the SCP of the case study), such as including stakeholders (e.g., governmental officials), non-stakeholders (e.g., property developers, bankers, scholar, experts, and the local residents). The core information was recorded and translated into English to further thematic code by NVivo Software (refer the question guide in Table 1). The nodes were used to code interview data and be input to the program (Oneda and Barros, 2020). All data were deleted after this study to ensure confidentiality. After all interviews, we have done the tri-angulation for finding out relevant secondary data sources from the recent published literature and governmental reports and publications to further support and validate the primary data collected from the SSI and FGA in this research are valid.

\section{RESULTS}

After the analysis of the SSI and FGA data, we conducted statistics on hot topics (the occurrence number is more than three times). At professional aspect, the hot topics are governance, standard, urban planning, building design, finance, and public perception in SSI. On the resident side, the hot topics are living environment, sporting and leisure places, housing price, personal income, jobs, and education (See Table 2, Figure 4). According to these hot words, the paper will further record and analyze these aspects in the following sections.

\section{Governance and Standard}

The Chinese governance framework includes National, Provincial, Municipal, County/District Government and Town Government (Yang et al., 2018). The governance system has a rigid top-down framework (see Figure 5). The high-level governments manage the low-level governments. The Gui'an New District Government is governed by Guiyang Municipal Government, Guizhou Provincial Government and China National Government. At all governing levels, each government independently manages ministries, departments, or bureaus (Guizhou Provincial Government, 2017; Guiyang Municipal Government, 2020; Yang et al., 2020).

China's history and developing condition have been shaped the governance arrangement characteristics (Ongaro et al., 2018). Governance arrangement is the key to long-term urban water management (Hegger et al., 2014). The major characteristics and barriers of the ongoing SCP governance are following: (1) Centralization. The SCP governance is centrally organized. The national authorities (e.g., National Development and Reform Commission) set general SCP standards and guidelines via legislation. The local governments take responsibilities on regional water issues according to local urban conditions (e.g., geography, precipitation and urban development). However, the implemented SCP till lacks localized governance in pilot sponge cities (Wu et al., 2020). (2) Cross-department governance. The SCP governance includes decision-making, planning, design, construction, operation and maintenance. Gui'an New District Bureau of Development and Reform, Bureau of Housing and Urban-Rural Development, Bureau of Ecological Environment, Bureau of Natural Resources, Bureau of Water Resources, respectively, take charge of funding, urban planning and designing, urban environment, water resources, flood issues. There is no clear organization to cooperate different participates (Dai et al., 2017). (3) State-dominated governance. The National departments dominated urban water management. None-state participants have less opportunity to give advice on SCP governance (Ehnert et al., 2018). Many respondents' expressions have validated the characteristics of SCP governance:

\footnotetext{
"[...] The National, Provincial and Municipal Government intensively influence the SCP policy. For example, National, Provincial and Municipal Government control the national investment, land resource, water resource and pollution license. The County/District and Town Governments have less chance to participate in the top policy domain. [...]" (Respondent A)
} 
TABLE 1 | Respondent characteristics and relevant information.

\begin{tabular}{|c|c|c|c|c|c|}
\hline $\begin{array}{l}\text { Fields/Work } \\
\text { background }\end{array}$ & Organization & $\begin{array}{l}\text { Respondent } \\
\text { code }\end{array}$ & $\begin{array}{l}\text { Educational } \\
\text { background }\end{array}$ & Main Topics/coding pattern & Question guideline (Excerpt) \\
\hline Government officers & $\begin{array}{l}\text { Guizhou Provincial } \\
\text { Government } \\
\text { Guiyang Municipal } \\
\text { Government } \\
\text { Gui'an New District } \\
\text { Government }\end{array}$ & $\begin{array}{l}\text { A } \\
\text { B } \\
\text { C }\end{array}$ & $\begin{array}{l}\text { Master Degree } \\
\text { Master Degree } \\
\text { Bachelor }\end{array}$ & $\begin{array}{l}\text { Governance, Management, } \\
\text { Standard, Urban Planning, } \\
\text { Public and Private Partnership } \\
\text { (PPP), SCP Practices }\end{array}$ & $\begin{array}{l}\text { (1) What is China's political governance system in SCP? } \\
\text { How is it made up? (2) How is power distributed in } \\
\text { different levels of government in SCP? What are their } \\
\text { respective responsibilities in SCP? (3) What are the } \\
\text { strengths and weaknesses of China's current } \\
\text { governance system in SCP? (4) What is the SCP } \\
\text { investment model? How does the current SCP } \\
\text { investment model work? (5) Is there any successful or } \\
\text { failure case? Please introduce some typical local SCP } \\
\text { cases. (6) Are there conflicts between public and private } \\
\text { needs in SCP? How to reconcile public and private } \\
\text { needs in SCP. }\end{array}$ \\
\hline \multirow[t]{5}{*}{ Bureau officers } & $\begin{array}{l}\text { Gui'an New District Bureau } \\
\text { of Development and Reform }\end{array}$ & $\mathrm{D}$ & Master Degree & & \\
\hline & $\begin{array}{l}\text { Gui'an New District Bureau } \\
\text { of Housing and Urban-Rural } \\
\text { Development }\end{array}$ & E & Bachelor & & \\
\hline & $\begin{array}{l}\text { Gui'an New District Bureau } \\
\text { of Ecological Environment }\end{array}$ & $\mathrm{F}$ & Master Degree & & \\
\hline & $\begin{array}{l}\text { Gui'an New District Bureau } \\
\text { of Natural Resources }\end{array}$ & $\mathrm{G}$ & Master Degree & & \\
\hline & $\begin{array}{l}\text { Gui'an New District Bureau } \\
\text { of Water Resources }\end{array}$ & $\mathrm{H}$ & Master Degree & & \\
\hline Property developers & $\begin{array}{l}\text { Local housing developer } \\
\text { Local housing salesman }\end{array}$ & I & $\begin{array}{l}\text { Bachelor } \\
\text { Bachelor }\end{array}$ & $\begin{array}{l}\text { Housing Price, Housing } \\
\text { Demand, Housing Design, Public } \\
\text { and Private Partnership (PPP), } \\
\text { Investment Return }\end{array}$ & $\begin{array}{l}\text { (1) Does SCP have any influence on housing price, } \\
\text { housing demand and housing design? How does the } \\
\text { influence manifest itself? (3) What is the investment } \\
\text { return ratio of SCP? (4) Has PPP investment model been } \\
\text { successfully applied to SCP? }\end{array}$ \\
\hline Banker & Local city bank & K & Bachelor & $\begin{array}{l}\text { Public and Private Partnership } \\
\text { (PPP), Interest Return }\end{array}$ & $\begin{array}{l}\text { (1) Whether or not banks are willing to lend to SCP } \\
\text { projects? (2) What role does bank play in PPP } \\
\text { investment mode? (3) Are there any successful or } \\
\text { unsuccessful PPP cases? }\end{array}$ \\
\hline $\begin{array}{l}\text { Local non-Government } \\
\text { Organization (NGO) }\end{array}$ & Institution of engineers & L & Bachelor & NGO and Public Participation & $\begin{array}{l}\text { (1) How much the public and NGO are involved in the } \\
\text { SCP? (2) How does they get involve? }\end{array}$ \\
\hline
\end{tabular}




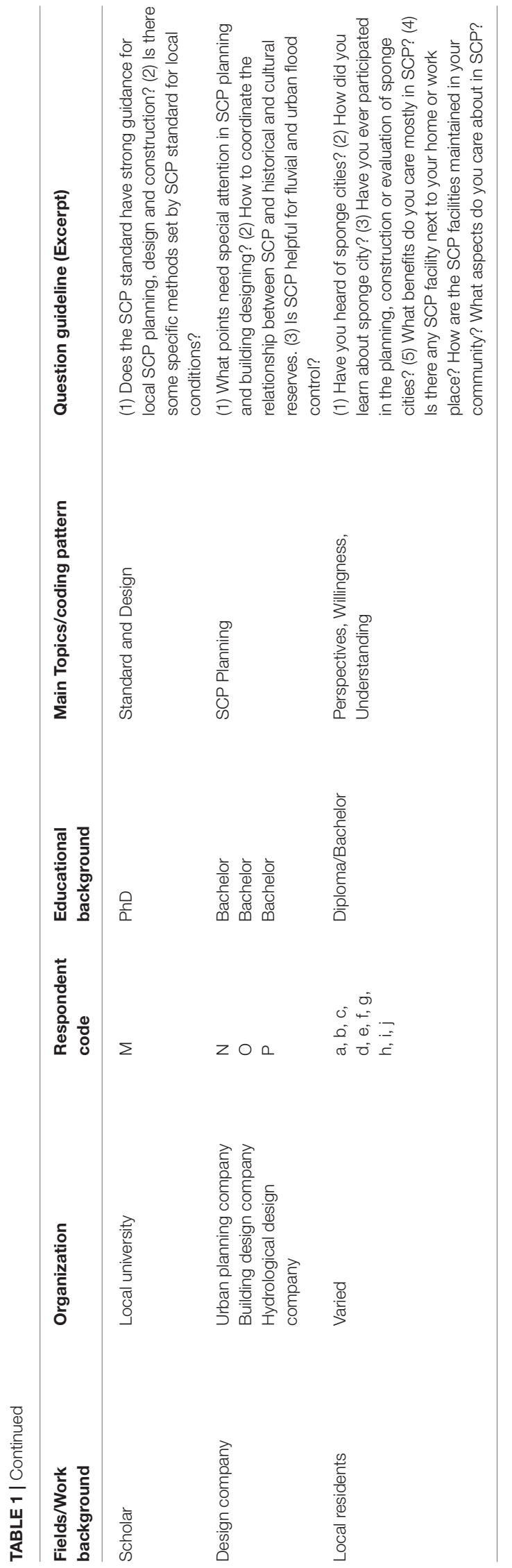

TABLE 2 | The mentioned times of hot topics.

\begin{tabular}{|c|c|c|c|}
\hline \multicolumn{2}{|c|}{ SSI } & \multicolumn{2}{|c|}{ FGA } \\
\hline Keywords & $\begin{array}{c}\text { Occurrence } \\
\text { number }\end{array}$ & Keywords & $\begin{array}{c}\text { Occurrence } \\
\text { number }\end{array}$ \\
\hline Finance & 15 & $\begin{array}{l}\text { Living } \\
\text { environment }\end{array}$ & 8 \\
\hline Governance & 14 & $\begin{array}{l}\text { Leisure } \\
\text { places }\end{array}$ & 7 \\
\hline $\begin{array}{l}\text { Planning and } \\
\text { Design }\end{array}$ & 12 & $\begin{array}{l}\text { Sporting } \\
\text { places }\end{array}$ & 6 \\
\hline Standard & 10 & Housing price & 5 \\
\hline $\begin{array}{l}\text { Building } \\
\text { Deign }\end{array}$ & 9 & Education & 4 \\
\hline $\begin{array}{l}\text { Public } \\
\text { perception }\end{array}$ & 7 & $\begin{array}{l}\text { Personal } \\
\text { income }\end{array}$ & 3 \\
\hline $\begin{array}{l}\text { Public } \\
\text { participation }\end{array}$ & 5 & Jobs & 3 \\
\hline
\end{tabular}

"[...] At the aspect of policy-making and urban planning, the County/District Government and Town Government have less authorities. In most cases, County/District Government play as actors of implementing policy and urban planning. Meanwhile, none-state participants cannot take part in the decision-making process. [...]" (Respondent B)

"[...] The centralized political system provides less opportunities to local governments to participate in top policy design and urban planning. There is an obvious disadvantage that the high-level policies and urban planning are too general to implement in all counties, districts and towns. [...]" (Respondent C)

"[...] The SCP governance involves many bureaus, such as Bureau of Development and Reform, Bureau of Housing and Urban-Rural Development, Bureau of Ecological Environment etc. These bureaus have their own authorities in SCP. Until now, there is no special organization to implement SCP in Guian. If they cannot cooperate with each other in SCP implementation, the SPC process will be slowdown. [...]" (Respondent D)

Another challenge is the SCP standards. The national governmental publications, such as "Technical Guidelines for Sponge City Construction (trial)" and "Assessment standard for sponge city construction effect (GB/T 51345-2018)," provide the earliest and unified evaluation criteria for SCP construction. The major assessment criteria are the following seven elements (Ministry of Housing Urban-Rural Development, 2014; Wenliang et al., 2018):

1) Decreasing annual surface runoff rate;

2) Effectiveness of SCP Infrastructures on water-source control;

3) Improving the urban flooding prevention;

4) Improving urban water environment;

5) Increasing water quality standard;

6) Recharging the underground water; and improving the stabilization of underground water level;

7) Alleviation of urban heat island effect. 


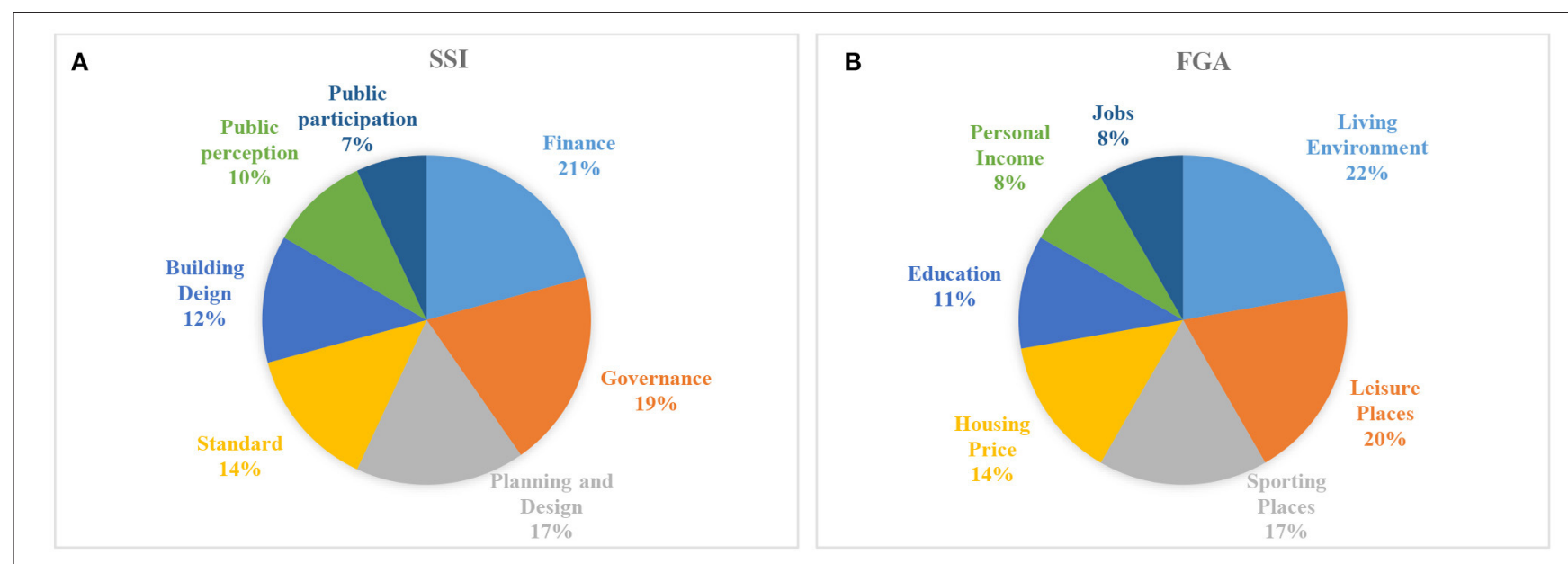

FIGURE 4 | The occurrence ratio of key topics in SSI (A); the occurrence ratio of key topics in FGA (B).

Because China has a large territory, national standards, and codes are hard to be designed for special regions (Jia et al., 2017). Several respondents regarded the SCP standards as too generalized to be applicable in all Sponge Cities where climate, hydrology and socio-economics are vastly different:

\section{"[...] until now, the SCP standards lead us to plan and design SCP infrastructures. However, the SCP standards are too general to be utilized in specific sponge cities. Universal indicators (e.g., green space coverage, green building ratio and urban plot ratio) are easy to manage, but are untargeted to local conditions (e.g., rainfall, geography, economic, culture, history and heritage of the city). The less consideration of local conditions in standards is an obstacle to SCP planning, construction and assessment. [...]" (Respondent M)}

The lacking of localized standards at city or district level, such as Gui'an technical standard for sponge city construction, effects on the accurate selection of criterion. However, the national standard, such as "Assessment standard for sponge city construction effect (GB/T 51345-2018)," partly overlooks precipitation patterns, hydrological, geomorphological and economic conditions. Gui'an New Distinct is located in a less developed inland mountainous area with relative lower building and population density to eastern mega cities such as Shanghai and Hangzhou. It is at high risk of pluvial flood, fluvial flood, and waterlogging disasters.

The National Standard (GB/T 51345-2018) classifies China into five general zones (I, II, III, IV, V). The Gui' an New Distinct and other coastal cities (e.g., Shanghai, Ningbo, Fuzhou) are in the same zone III, which means the surface runoff reduction rate is the same (between 75 and 85\%) (Wenliang et al., 2018). However, Gui'an New District is rarely affected by typhoons, unlike the other coastal cities in zone III. The neglection of local climate and geographic factors in national SCP standards is thus a key challenge, as the idea of "one solution fits all" is not suitable.

\section{Planning and Design}

The State Council requires that over $20 \%$ of urban areas should be transformed to sponge area by 2020, and further reach $80 \%$ by 2030 (General Office of the State Council, 2015). In the case of Gui'an, the reduction rate of urban surface runoff has been set as the rigid target, the authorities (e.g., Local Water Bureau and Planning Bureau), which has to be achieved these bars as the top-prioritized criterion. Major objectives of the SCP has been further extended to incorporate sustainable urban development (e.g., water environment treatment and restoration, carbon emission reduction, urban heat island effect reduction, smart city development) (Jia et al., 2017). The SCP in the planning perspective is encouraging, but at the same time that seems too ambitious as illustrated by the interview participants below.

"[...] The guideline neglects the local government financial capability. The SCP is still highly depending on subsidies. If there are no subsidies from National, Provincial and Municipal Government, Guian New District cannot afford build more SCP infrastructures to meet the urban runoff reduction rate. [...]" (Respondent E)

The high targets, such as sponge area rate, are definitely beneficial to accelerate SCP development. Planning more SCP areas in cities means the decrease of land sales (Long et al., 2020). At present, land sales income is one key source of government budget and SCP funding. Considering the unbalanced economic conditions in the Chinese cities, the promotion and implementation of SCP goals are uncertain. In Gui'an case, there is a competition for land use between urban ecology and economic development, as highlighted by several interview and focus group respondents:

"[...] The land use has obviously effect on the spatial expansion of sponge city. The city land is scarce and valuable due to increasing population and buildings. The SCP infrastructures are mostly designed on open land, which requires more land resources than underground infrastructures (e.g., discharge system). The local governments still severely depend on the income of land sales. 


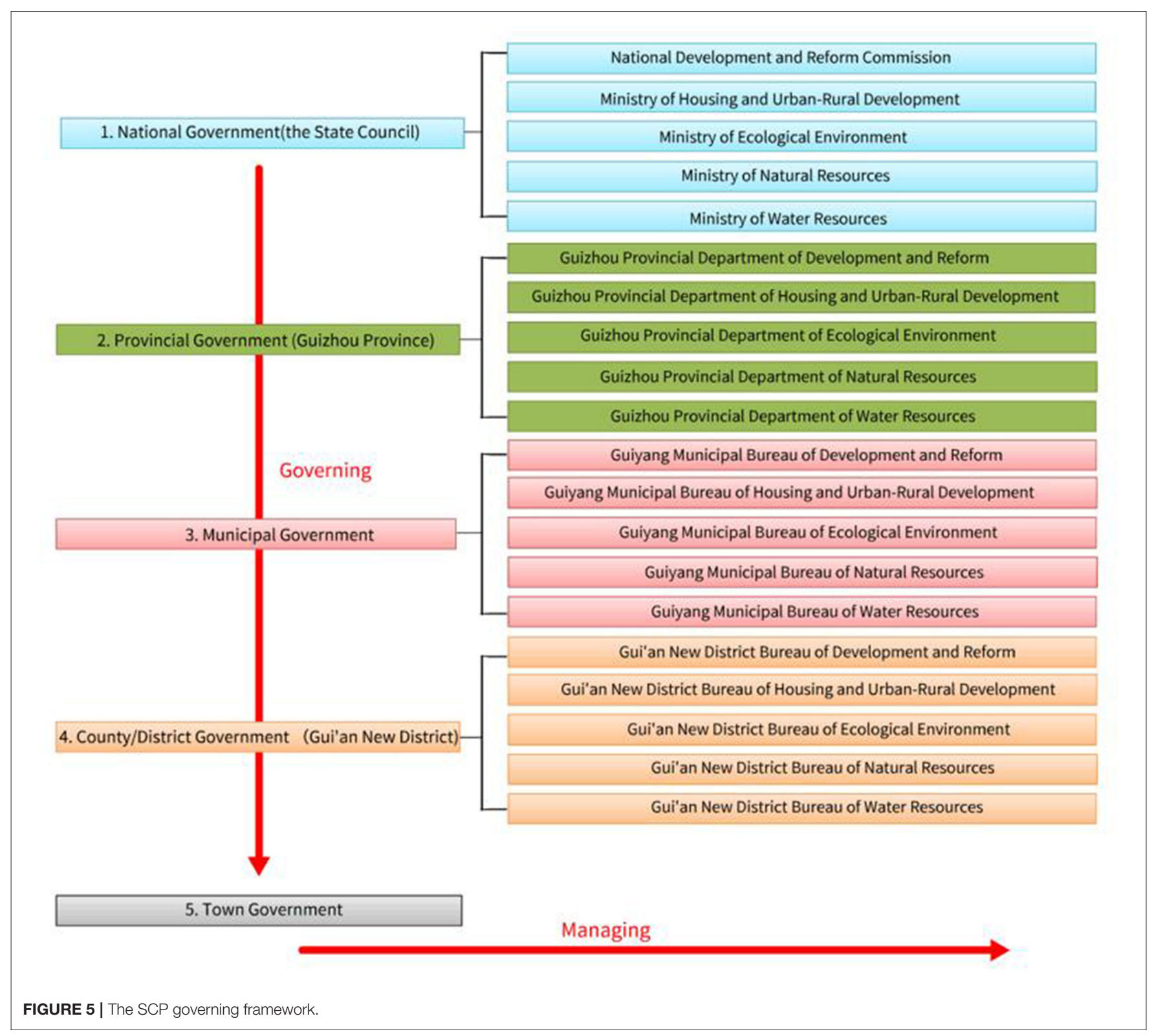

The decrease of land sales means the decrease of local government income. [...]" (Respondent G)

At the SCP designing aspect, most urban designers highly focus on their customer needs (governments or developers). The governments and developers, respectively, represent public and commercial demands. The designers only focus on a "one-way road" that only concerning about the public interest or business development is not enough in SCP design. The difficulty is how to integrate the existing and planned public infrastructures (e.g., roads, drainage system, dams, levees, and wetland parks) adequately and timely to commercial SCP facilities (e.g., green business and residence buildings). An official of Gui'an New District Bureau of Water Resources stated:
"[...] The public demand is usually inconsistent with commercial demand. For example, the public demand of SCP is to improve flood prevention ability, public healthy and urban environment. The developers need increase the housing price via commercial SCP facilities. The two kinds of requirements are hard to reconcile. [...]"

(Respondent $\mathrm{H}$ )

From a cultural and heritage perspective, the questions of protecting, and enhancing the conservation of historical features are prominent. The management dimension of the protection of cultural heritage in the SCP planning areas is currently not considered by the 2014 SCP guidelines and subsequent assessment criteria in 2018. For example, Qingyan Ancient Town is in the SCP planning zone in Gui'an New District (Figure 6). We explored the viewpoints of urban planners and designers 

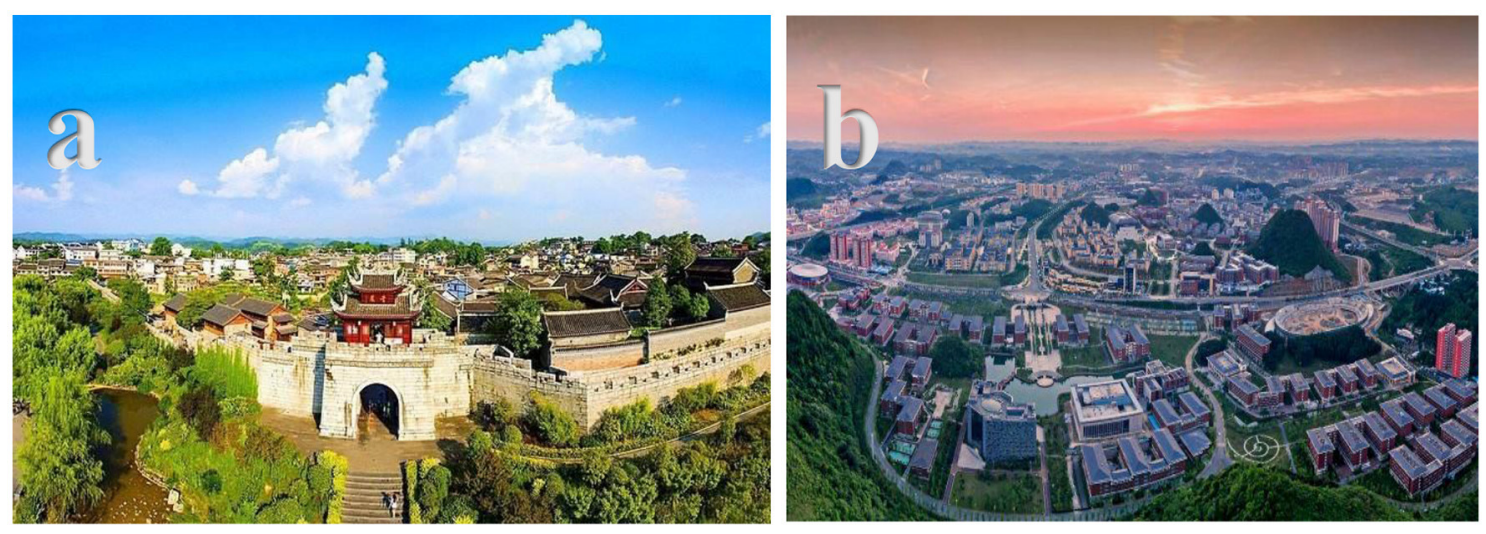

FIGURE 6 | Qingyan Ancient Town in Gui'an New District (a); University Town in Gui'an New District (b) (Photographed by authors).

about delivering the SCP in cultural relic protection areas (e.g., Qingyan Ancient Town):

\section{"[...] The Qingyan Ancient Town is in core area of Guian New District. How to coordinate SCP with an ancient town is a huge challenge in urban planning and building design. It is difficult to integrate historical architectural features with modern engineering measures. There are also many law limitations on construction process. [...]" (Respondent $\mathrm{N})$.}

According to the "Architectural Feature Guideline of Guian," most building roofs in Gui'an central area must be built with a sloping roof to align with the traditional building style. However, green roofs are only suitable for roofs with $<15$-degree slope (Gui'an Urban Planning and Construction Bureau, 2018) hence only suitable for some areas out of Gui' an central area.

\section{Finance}

The National Government has subsidized every pilot sponge city, providing RMB 400-600 million from 2015 to 2018 (Dai et al., 2017). The subsidies are far from enough to transform a city into a "sponge," which requires at least RMB 100 million per $\mathrm{km}^{2}$ (Xiang et al., 2019). The funding issue is a huge challenge for the next stage of the SCP, as highlighted by the interview respondents.

"[...] The SCP construction requires huge investment. The first stage of SCP in pilot sponge cities highly depends on the subsidies from National Government. If there are no additional subsidies, the SCP will be limited in small pilot areas. We have to initiate more investment model to implement SCP in the urban scale. [...]" (Respondent K)

In order to solve the funding issue, the Chinese government has promoted the Public and Private Partnership (PPP) investment model since 2016 (Zhang et al., 2019). Although the interview respondents regard this with limited success:

"[...] The PPP investment model is not mature to all investors. The investment policy, investment objective and cooperative willingness still have problems. In most cases, the two kinds of investors (public and private investors) are hard to be coordinated. [...]" (Respondent I)

The National Development and Reform Commission and Ministry of Finance drafted the PPP policy. The investment and potential returns are different in different cities and sponge infrastructures. Indeed, the PPP policy is too general to implement in all projects. A contradiction typically exists between public and private investors. Public investors require maximization of the public benefits of an investment (e.g., improving urban landscape and flood prevention), whereas private investors focus on financial benefits (at least $8 \%$ financial return rate) (Zhang et al., 2019). Interviewees mentioned the contradiction:

"[...] Different objectives make them hard to achieve cooperation. In Guian New District, the Yueliang Lake Park, Xingyue Lake Park and Chetian River Park used PPP investment model with the total investment of 2 billion RMB (Figure 7). The distribution of cost and return has yet to be resolved. [...]" (Respondent D)

Unlike power stations and sewage treatment plants, the SCP infrastructure cannot generate stable financial returns hence private investors are reluctant to invest in these projects. In this case, the private sector is typically state-owned companies, which have the most capital and talented people in China; but the private companies are relative smaller. The imbalance makes the state-owned companies reluctant to cooperate with private companies. In fact, the enthusiasm of private investors appears to be waning. Compared to 2019, the PPP projects decreased by $25 \%$ in 2020; and the implemented PPP projects sharply dropped by $61 \%$ (Sohu News, 2020). The current funding policy could become major obstacles to scale up national SCP. The National Government has tried to improve the PPP policy from 2017 to 2020. Until now, the improvement is limited on SCP investment.

\section{Public Perception}

The support of local residents is key to the success of the SCP. Except for some professionals and well-educated people, all 



FIGURE 7 | Sponge parks in Gui'an New District. Chetian River Park (a); Yunman Lake (b); underground tank (c); water front path (d). (Photographed by authors).

residents (10 in 10 residents) have only heard news about the SCP from the Public Medias such as TV, apps, new paper, and website. The reason will be further discussed in section Discussion.

The residents in the FGA have a common perception that the SCP can improve the urban environment (8 in 10 residents in FGA mentioned). They enjoyed the local recreational (7 in 10 residents in FGA mentioned) and sporting entertainment measures (6 in 10 residents in FGA mentioned) in the SCP infrastructures (e.g., wetland park and waterfront trail exercise tracks). They believed the SCP could raise the local housing prices (5 in 10 residents in FGA mentioned). They also want to get more multiple benefits (e.g., rising housing price, higher educational quality, more personal income and more job opportunities) from SCP. There are two typical statements as follow to validate the results as here:

"[...] the public awareness of SCP is from TV, smart phone and website. The public perception is on entertainment, sports and housing price. [...]" (Respondent a).

"[...] When the SCP projects are built up, the assessment team usually consists with experts and officials but no residents. The real feelings of locals are neglected by the team, which is not conductive to improve the public perception of SCP" [...]. (Respondent M)

Residents' perspectives are not typically identified during the SCP planning phase. The channel of public participation is mostly via official websites yet the official online participation cannot effectively collect residents' real ideas to solve the local issues. In fact, respondents (residents) in FGA never took part in any online participant activities. More residents' opinions should be solicited via a range of channels (e.g., community surveys, school education, brochure and invitation for project visits).

SCP infrastructure also require regular maintenance. This varies by SCP facilities and local conditions. Maintenance can be as simple as removing marshes and debris in wetlands and river, or as complex as maintaining ecological sustainability and diversity. The challenge identified by FGA respondents is maintaining SCP infrastructures on private properties;

"[..] The Public SCP infrastructures (e.g., wetland parks) are usually at good maintenance. The challenge in SCP maintenance is in private houses, apartments and communities. The local residents have a common perspective that they have no compulsive responsibilities to maintain $S C P$ facilities in their own properties. [...]" (Respondent b).

"[...] For example, residents have removed green balconies and lawns to create larger indoor or parking spaces. On the other hand, the public buildings generally have better maintenance on SCP facilities. The public awareness on infrastructure maintenance needs to be improved in SCP operation. [...]" (Respondent c) (See Figure 8).

\section{DISCUSSION}

China has made a huge decision to develop sustainable city via SCP. If cities cannot achieve the goals to SCP mentioned in section Case Study-Background, China government will fail to deliver on original promises to the world. The cities will face severer urban flood, waterlogging, urban water pollution, 


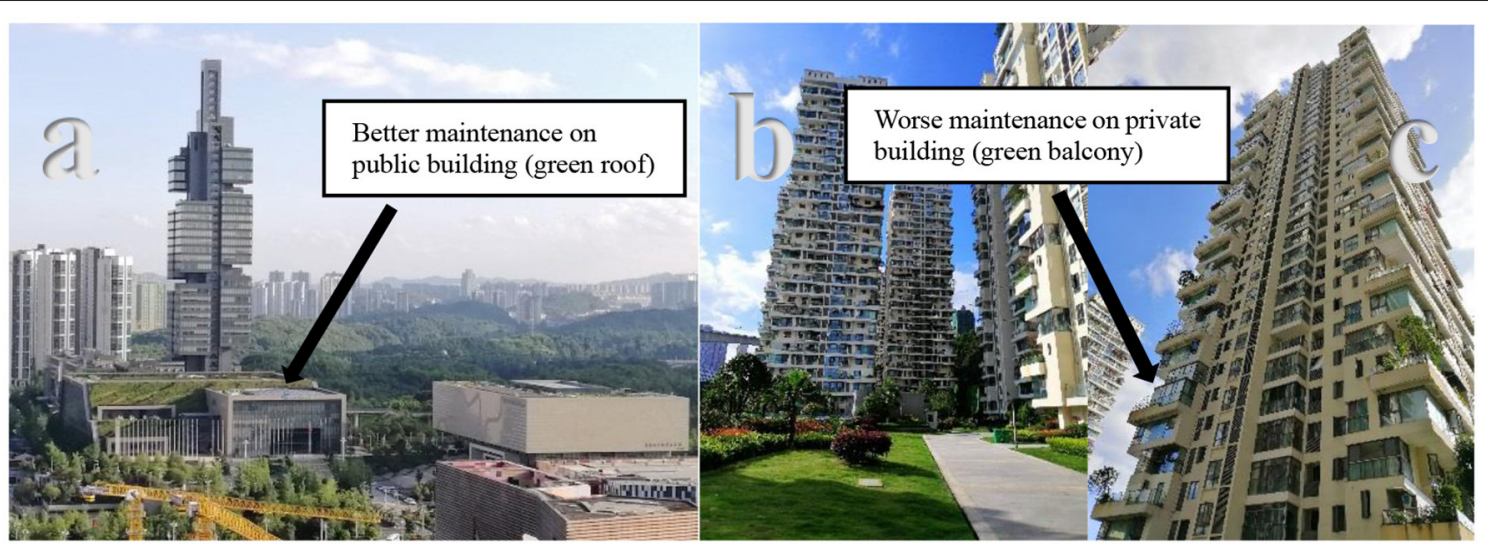

FIGURE 8 | Operation and maintenance conditions in Public (a)/Private (b,c) buildings (Photographed by authors).

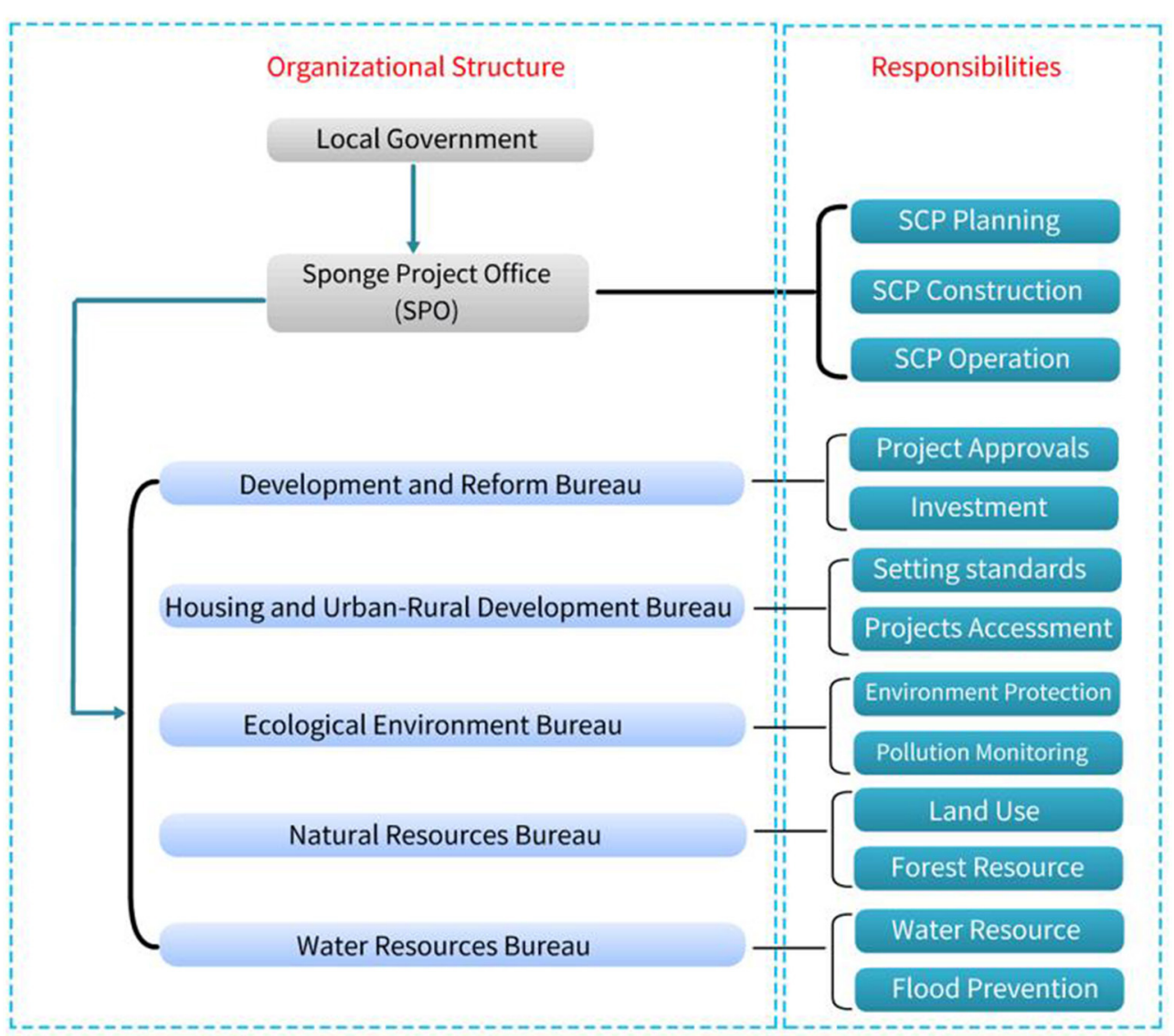

FIGURE 9 | Sponge Project Office authorized by the local district government (Source: authors).

social well-being, and urban eco-system services issues. Through the results, be found in case study, via SSI and FGA, the paper identified the main challenges of SCP in Gui' an New District are governance, standard, planning and design, finance, and public perception. The following section will find the possible solutions.

\section{Establishing an Overarching SCP Organization}

The SCP involves different knowledge and governing fields. In Gui'an, the collaboration within bureaus is not working very closely. For example, the Development and Reform Bureau mainly manage the project approvals; the Housing 
and Urban-Rural Development Bureau focus on the urban planning and building design; Ecological Environment Bureau manages urban environment issues; Natural Resources Bureau manages land use, and; Water Resources Bureau manages urban water issues. Each bureau has its responsibility in current SCP management (Yang et al., 2020).

The complex organizational structure makes SCP management ineffective. Informed by data collected in SSI and FGA. A Sponge Project Office (SPO) can be established under local government. The SPO can be a special organization (not a bureau) directly leaded by local government. It has higher authority to order different bureaus. Local government authorizes the SPO to coordinate all bureaus in planning, construction and operation (See Figure 9). The SPO can manage the whole implementation process (e.g., planning, designing, building, and assessment) to improve organizational efficiency. According to the different local conditions, the SPO can be modified to improve adaptability. For example, in Gui'an, the assumed SPO can purchase urban planning services from consulting companies if there is a lack of local SCP engineers. In order to reduce the contradiction within different bureaus, the SPO can invite officials from related bureaus to have a joint review.

\section{Deep Integration With Urban Planning via Suitable SCP Strategies}

Different SCP measures are suitable for different climatic, geographical, hydrological and geological conditions. Many SCP measures cannot be directly transferred from one place to another. Northern China cities in plain areas (e.g., Tianjin, Beijing and Jinan) are facing the problems of groundwater decline, water pollution, and water shortage. The coastal cities (e.g., Guangzhou, Xiamen, Ningbo, and Shenzhen) are suffering from storm surges (Griffiths et al., 2020). Other inland cities (e.g., Wuhan, Nanchang, and Nanjing) in middle-catchment Yangtze River are effected by fluvial floods (Chan et al., 2018). In Gui'an, the ideal choice is building soil and water conservation infrastructures to reduce natural hazards (e.g., retaining wall) ( $\mathrm{Li}$ et al., 2019). The SCP guidelines and standards should contain more designs (e.g., mountain parks) specific to challenges experienced in mountainous regions.

Urban flood standard of urban drainage system only reaches 1-in-5 year in Gui' an New District at present. The SCP guideline mostly requires a 1 -in-30 year standard. However, urban flood prevention capacity needs to be at a 1-in-100 year standard (Ping et al., 2016). It is hard to meet the SCP urban flood standard by only using SCP infrastructures. For example, the rain gardens and storage tanks can be filled quickly during intensive rainfall events. In Gui'an, the SCP infrastructures mainly improve the urban landscape. Gray infrastructure still plays an important role in urban flood prevention. Making the gray infrastructures more environmental-friendly and developing green-gray infrastructures are the future paths of SCP (Thorne et al., 2015). The similar statement was collected in SSI:
"[...] the dams and levees are sill the main force to prevent the city from the pluvial and fluvial floods. The SCP infrastructures, such as rain gardens and wetlands, have limited flood prevention capacity. Making the gray infrastructures to be more environmental-friendly is a reasonable way of sustainable urban flood management in future. [...]" (Respondent $\mathrm{H}$ ).

The SCP need an orderly development (Wu et al., 2020). Deeper integration of SCP and urban planning is necessary. Localized SCP standards must consider geographical, meteorological and economic conditions and align with urban planning. The SCP should be implemented by batches/regions/levels to form a multi-area and networking layout city ( $\mathrm{Li}$ et al., 2017). Meanwhile, urban planning should actively adopt the SCP and continuously be modified. In the process, the SPO can act as a coordinator within various specialized planning divisions (e.g., national economic and social development planning, land use planning, water system planning, fluvial flooding control planning, urban surface flooding control planning, traffic planning, green space system planning, tourism development planning, and ecological protection planning) (Griffiths et al., 2020).

\section{Transform the SCP Into a Financially Sustainable Program}

As the SCP involves many stakeholders (governments, investors, developers and residents), promoting cooperation among them is an effective way to implement a financially sustainable SCP (Tang et al., 2018). Transforming the SCP into a "win-win" financial solution is important. The construction of SCP infrastructure provides a better living environment for residents. However, SCP infrastructures usually mean low investment return for investors. Considering the whole life-cycle cost, more reasonable investment models should be introduced to SCP practices. An example is that the local government can repackage the SCP with nearby land into a new project. The housing developers will have motivation to invest in SCP infrastructure (Zhang et al., 2019). The water company have stable income from water bills paid by residents. The sewage plant has stable income from treatment fees paid by local government. If the local SCP package can include the construction and operational rights for waterworks and sewage plants, the SCP can attract more potential private investors.

Another example is the rooftop photovoltaic power stations, which can increase income to residents. Packaging the rooftop photovoltaic power station with rooftop gardens, and providing installation subsidies to residents, can motivate residents to develop rooftop SCP facilities (He et al., 2019). The residents can also benefit from a rooftop garden that may improve their happiness and health (reduction of medical expenses). Meanwhile, a better living and business environment would attract more companies to provide job opportunities to residents. The local stormwater policy and practice has yet to establish in China. Similarly, also to the current carbon reduction and carbon budget policy, the citizens who have higher rainwater discharge volume can subsidize people with low rainwater discharge 
volume. The assumed rainwater discharge exchange policy can motive residents to build SCP infrastructures (Jia et al., 2017).

Indeed, a financially sustainable SCP requires the government sacrificing income and providing more subsidies to private investors or individuals. It will obviously increase the financial pressure to local governments. The financial balance points are difficult to find due to the different government budget and tax income. Local government can have a financial pressure test (investment-debt test) when choosing different investment packages and finding the specific financial balance point.

\section{Improving SCP Assessment Mechanisms}

Although the China National Government has published "Assessment standard for sponge city construction effect (GB/T 51345-2018)," it has less principles about project economic efficiency evaluation that also applies in the case of Gui'an (Yang et al., 2020). Given the enormous costs involved and the need to make substantial changes to governance and planning, the economic efficiency of SCP investments has become more important. For example 4.67 billion yuan (RMB) has been invested during the first stage of the SCP in Gui'an (Yang et al., 2020).

The pre-assessment need economically evaluates SCP projects comparing with traditional engineered measures (Chang and Su, 2020). The direct comparison of economic costs and benefits can guide decision-making and project selection to maximize the utilizing value of limited resources (Raymond et al., 2017). By post-evaluating the benefits and costs of implemented pilot SCP projects, the economic efficiency assessment can help the local government in Gui'an to further improve and optimize the SCP standard.

Still, it is a difficult task to compare SCP measures from an economic perspective in the policy field characterized by technocratic governing ideas. After decades of rapid development, China has accumulated a lot of experience in engineering techniques for urban construction. From the perspective of the construction industry, the traditional engineering measures may have lower economic costs in the short term due to mature technologies. The SCP measures is new to the construction industry. The scientific research cost, transaction cost, and cross-department cost could be hard to be estimated, which brings more uncertain risks for investors (Ding et al., 2019).

However, much of the initiative benefits comes from efficiency gains in social aspects rather than financial one. The pilot projects should further detailed document information on the costs and benefits in social side, which may help support the identification of a more sustainable option to attract more investors from the private sector.

\section{Improving Public Participation}

As mentioned in section Results, we found that most local residents in Guiyang have actually heard about SCP from the Public Media channels. The FGA results in this case study were also validated by willingness research paper (Ding et al., 2019) and public perception research paper (Yutao et al., 2017). This gave a credit to the Chinese centralized media management. If the municipal authorities need to promote and implement a policy or program, the local government will promote and advertise the policy or program in various media channels (e.g., via Television programs, Radio broadcasting channels, Newspapers, online news, social media channels-WeChat, Weibo, etc.). The integrated media management enables the public to quickly know a new policy, which is conducive to the prompt policy implementation (Xiaoping et al., 2020). Nevertheless, the perception of residents on SCP is superficial. The awareness is mainly on meeting personal demand such as living environment, leisure and sporting place, housing price, education, income, and jobs, which was also reflected in FGA results.

In the past, one-fifth of Chinese cities have "image projects"; constructions for rising a city's profile rather than practical use (China Daily, 2010), likely due to a lack of public participation and monitoring. In order to decrease the risk of "image projects" in the SCP, one solution is to further increase public participation. The SCP planning should be fully publicized to most stakeholders through various channels (e.g., internet, $\mathrm{TV}$, newspapers, magazines, community classes, and school education) before project approval (Liang et al., 2020). The respondent expressed the similar viewpoint:

"[...] in the past, a small part of authorities has invested on "image projects" such as a huge pseudo-classic architecture in Dushan County, Guizhou Province. These projects wasted tax money. We concern the SCP would develop in that way. We want to participate and monitor the decision making to improve the investing efficiency via various channels. [...]" (Respondent $\mathrm{H}$ ).

The public participation is mostly via official websites. The official online participation model may not be accessible to certain group, such as the elderly or non-professional people. More education and outreach should be undertaken in communities and schools to further increase deeper understanding of the SCP. Meanwhile, planners should adjust SCP planning after collecting feedbacks from the public. At the operational and maintenance stage, the perspectives of owners, users and nearby residents of SCP infrastructure should be fully collected. In order to improve public participation, governments could provide certain subsidies to Non-Government Organization (NGO) to carry out activities of education, outreach, surveys and interviews. Referring to planning and designing engineers, a SCP professional qualification examination or certification can be promoted. More talents that involve with current and future SCP can be trained to sustain further development and delivery of successful practices at the final stage of the SCP (from now up to 2030s and beyond).

\section{CONCLUSION}

Chinese cities are suffering from a range of urban water issues (e.g., flooding, waterlogging, water pollution, and water ecological system degradation) which provides an opportunity to develop sustainable urban water management. The SCP arguably 
is a vivid metaphor that describes the urban surface naturally absorbs rainwater. We are supporting the future development of SCP.

Indeed, the SCP can partly address the current urban water issues, in prior to transforming the Chinese cities toward more sustainable developing way. Through in-depth interviews of many stakeholders, we have explored the current governmental institutional arrangement, social engagement, and financing challenges of the SCP and the opportunities for further promotion SCP in Gui'an New District.

The governance system in China is centralized and hierarchy based with the strong influence from the National Government and the affiliated policies, which the reasons the SCP can be progressed and delivered across pilot cities in China. In fact, we understood the municipal government has paid substantial efforts to address the shortcomings in SCP to improve the quality of service.

However, the bottom-up and Civil Society concepts are still not popular in the Chinese context. Stakeholders and the municipality authorities have realized the importance of enhancing better public participation in SCP. Taking the multiple benefits of SCP forward, we would like to address some recommendations such as optimizing the organizational structure (i.e., setting SPO), further integrating with the SCP on the urban planning system (i.e., Master Plans), localizing SCP standards by considering the specific geographical (i.e., Guiyang as a valley city in this case study) and social-economic conditions.

Whilst, we recommend that the municipal government might consider to promote Green Finance to increase more common interests to enhance financial sustainability of SCP. The authorities may also target to improve the current assessment and benchmarking mechanisms by collecting feedbacks of stakeholders.

\section{REFERENCES}

Bjørnholt, M., and Farstad, G. R. (2012). 'Am I rambling?' on the advantages of interviewing couples together. Qual. Res. 14, 3-19. doi: $10.1177 / 1468794112459671$

Bolderston, A. (2012). Conducting a research interview. J. Med. Imaging Radiat. Sci. 43, 66-76. doi: 10.1016/j.jmir.2011.12.002

Catherine, S. R., Kirsti, N., and Marie, L. R. (2019). Conducting the Reference Interview. 3rd Edn. New York, NY: Neal-Schuman.

Chan, F. K. S., Griffiths, J. A., Higgitt, D., Xu, S., Zhu, F., Tang, Y.-T., et al. (2018). "Sponge City" in China-A breakthrough of planning and flood risk management in the urban context. Land Policy 76, 772-778. doi: 10.1016/j.landusepol.2018.03.005

Chan, F. K. S., Wright, N., Cheng, X., and Griffiths, J. (2014). After sandy: rethinking flood risk management in Asian Coastal megacities. Natural Hazards Rev. 15, 101-103. doi: 10.1061/(ASCE)NH.1527-6996.0000117

Chan, F. K. S., Zhu, F., Li, L., Lu, M., Tang, Y.-T., and Griffiths, J. (2020). The Champion of Urban Water Resources Management in the Chinese City-The Case of Ningbo. Singapore: Springer. doi: 10.1007/978-981-159605-6_25

Chang, H. S., and Su, Q. (2020). Research on constructing sponge city indicator and decision evaluation model with fuzzy multiple criteria method. Water Environ. Res. 92, 1910-1921. doi: 10.1002/wer.1344

\section{DATA AVAILABILITY STATEMENT}

The original contributions presented in the study are included in the article/supplementary material, further inquiries can be directed to the corresponding author/s.

\section{ETHICS STATEMENT}

The studies involving human participants were reviewed and approved by Faculty of Science and Engineering Research Ethics Committee at University of Nottingham Ningbo China. All interviewees consented to participate in this research.

\section{AUTHOR CONTRIBUTIONS}

All authors listed have made a substantial, direct, and intellectual contribution to the work and approved it for publication.

\section{FUNDING}

We would like to send our gratitude for the support from the National Natural Science Foundation of China (NSFC) (Grant number: 41850410497); the National Key R\&D Program of China (Grant number: 2019YFC1510400); the National Natural Science Foundation of China (NSFC) Youth Project (Grant number: 51909126); University of Nottingham (UNUK) project (Grant number: E01200500006); the Foundation of Science and Technology Department of Guizhou Province (Grant number: 20192879); the Institute of Asia Pacific Studies research funded for the Environmental Security and Sustainability; the Cultural and Creative Industries Research Priority Areas; also the Faculty of Science and Engineering (FoSE) Postgraduate Research Scholarship of University of Nottingham Ningbo China.

Chen, Y., and Chen, H. (2020). The collective strategies of key stakeholders in Sponge City construction: a tripartite game analysis of governments, developers, and consumers. Water 12, 1-18. doi: 10.3390/w12041087

Cheng, X. (2005). Changes of flood control situations and adjustments of flood management strategies in China. Water Int. 30, 108-113. doi: 10.1080/02508060508691842

China Daily. (2010). 'Landmarks' Smear Image (2010). Available online at: https:// www.chinadaily.com.cn/china/2010-06/23/content_10005886.htm (accessed December 31, 2020).

Dai, L., van Rijswick, H. F. M. W., Driessen P. P. J., and Keessen, A. M. (2017). Governance of the Sponge City programme in China with Wuhan as a case study. Int. J. Water Resour. Dev. 34, 578-596. doi: 10.1080/07900627.2017.1373637

Ding, L., Ren, X., Gu, R., and Che, Y. (2019). Implementation of the "sponge city" development plan in China: an evaluation of public willingness to pay for the life-cycle maintenance of its facilities. Cities 93, 13-30. doi: 10.1016/j.cities.2019.04.007

Edwards, R., and Holland, J. (2013). What Is Qualitative Interviewing?. London: Bloomsbury Academic.

Ehnert, F., Kern, F., Borgström, S., Gorissen, L., Maschmeyer, S., and Egermann, M. (2018). Urban sustainability transitions in a context of multi-level governance: a comparison of four European states. Environ. Innovat. Soc. Trans. 26, 101-116. doi: 10.1016/j.eist.2017.05.002 
Galletta, A., and Cross, W. E. (2013). In Mastering the Semi-Structured Interview and Beyond: From Research Design to Analysis and Publication. New York, NY: NYU Press. doi: 10.18574/nyu/9780814732939.001.0001

General Office of the State Council (2015). Guidelines on Promoting Sponge City Construction. Beijing.

Griffiths, J., Chan, F. K. S., Shao, M., Zhu, F., and Higgitt, D. L. (2020). Interpretation and application of Sponge City guidelines in China. Philos. Trans. A Math. Phys. Eng. Sci. 378:20190222. doi: 10.1098/rsta.2019.0222

Gui'an Urban Planning and Construction Bureau (2014). Urban Master Planning for Gui 'an New District (2013 2030). Guiyang.

Gui'an Urban Planning and Construction Bureau (2018). Permit to Sponge City Construction Plan of the Central Area of Guian New District.

Guiyang Municipal Government (2020). The Sponge City Planning of Guiyang Central City (2019-2030). Guiyang.

Guizhou Meteorological Bureau. (2020). Guizhou Meteorological Annual Report. Available online at: http://gz.cma.gov.cn/ (accessed October 20, 2020).

Guizhou Provincial Government. (2017). A Notice on Accelerating Sponge City Construction. Guiyang.

He, B.-J., Zhu, J., Zhao, D.-X., Gou, Z.-H., Qi, J.-D., et al. (2019). Co-benefits approach: opportunities for implementing sponge city and urban heat island mitigation. Land Use Policy 86, 147-157. doi: 10.1016/j.landusepol.2019.05.003

Hegger, D. L. T., Driessen, P. P. J., Dieperink, C., Wiering, M., Raadgever, G. T. T., and van Rijswick, H. F. M. W. (2014). Assessing stability and dynamics in flood risk governance. Water Resour. Manage. 28, 4127-4142. doi: 10.1007/s11269-014-0732-x

Hydrology Bureau of Guizhou Province. (2015). Flood Report of Guizhou Province. Guiyang.

Jia, H., Wang, Z., Zhen, X., Clar, M., and Yu, S. L. (2017). China’s sponge city construction: a discussion on technical approaches. Front. Environ. Sci. Eng. 11, 1-11. doi: 10.1007/s11783-017-0984-9

Jiang, Y., Zevenbergen, C., and Ma, Y. (2018). Urban pluvial flooding and stormwater management: a contemporary review of China's challenges and "sponge cities" strategy. Environ. Sci. Policy 80, 132-143. doi: 10.1016/j.envsci.2017.11.016

Lancia, M., Zheng, C., He, X., Lerner, D. N., Andrews, C., and Tian, Y. (2020). Hydrogeological constraints and opportunities for "Sponge City" development: Shenzhen, southern China. J. Hydrol. 28:100679. doi: 10.1016/j.ejrh.2020.100679

Lashford, C., Rubinato, M., Cai, Y., Hou, J., Abolfathi, S., Coupe, S., et al. (2019). SuDS \& Sponge Cities: a comparative analysis of the implementation of pluvial flood management in the UK and China. Sustainability 11, 1-14. doi: $10.3390 /$ su11010213

Li, H., Ding, L., Ren, M., Li, C., and Wang, H. (2017). Sponge City construction in China: a survey of the challenges and opportunities. Water 9:594. doi: $10.3390 /$ w9090594

Li, L., Collins, A. M., Cheshmehzangi, A., and Chan, F. K. S. (2020). Identifying enablers and barriers to the implementation of the Green Infrastructure for urban flood management: a comparative analysis of the UK and China. Urban Forestry Urban Greening 54:126770. doi: 10.1016/j.ufug.2020. 126770

Li, Q., Wang, F., Yu, Y., Huang, Z., Li, M., and Guan, Y. (2019). Comprehensive performance evaluation of LID practices for the sponge city construction: a case study in Guangxi, China. J. Environ. Manage. 231, 10-20. doi: 10.1016/j.jenvman.2018.10.024

Liang, X., Liang, Y., Chen, C., and van Dijk, P. M. (2020). Implementing water policies in China: a policy cycle analysis of the sponge city program using two case studies. Sustainability 12:5261. doi: 10.3390/su121 35261

Long, H., Qu, Y., Tu, S., Zhang, Y., and Jiang, Y. (2020). Development of land use transitions research in China. J. Geograph. Sci. 30, 1195-1214. doi: 10.1007/s11442-020-1777-9

Ministry of Housing and Urban-Rural Development. (2014). The Construction Guideline of Sponge City in China-Low Impact Development of Storm Water System (trail). Beijing.

Nguyen, T. T., Ngo, H. H., Guo, W., and Wang, X. C. (2020). A new model framework for sponge city implementation: emerging challenges and future developments. J. Environ. Manage. 253:109689. doi: 10.1016/j.jenvman.2019.109689
O’Donnell, E. C., Lamond, J. E., and Thorne, C. R. (2017). Recognising barriers to implementation of Blue-Green Infrastructure: a Newcastle case study. Urban Water J. 14, 964-971. doi: 10.1080/1573062X.2017.1279190

O'Donnell, E. C., and Thorne, C. R. (2020). Drivers of future urban flood risk. Philos. Trans. A Math. Phys. Eng. Sci. 378:20190216. doi: 10.1098/rsta.2019.0216

Oneda, T. M. S., and Barros, V. G. (2020). On stormwater management master plans: comparing developed and developing cities. Hydrol. Sci. J. 66, 1-11. doi: $10.1080 / 02626667.2020 .1853131$

Ongaro, E., Gong, T., and Jing, Y. (2018). Toward multi-level governance in China? Coping with complex public affairs across jurisdictions and organizations. Public Policy Admin. 34, 105-120. doi: 10.1177/0952076718799397

Onwuegbuzie, A. J., Dickinson, W. B., Leech, N. L., and Zoran, A. G. (2009). A qualitative framework for collecting and analyzing data in focus group research. Int. J. Qualit Methods. 1-21. doi: 10.1177/160940690900800301

Ping, H., Hong, L., Yuyan, C., Kun, S., Dongkang, Y., Hongsong, C. et al., (2016). Code for Urban Planning on Flood Control (GB 51079-2016). Beijing: Ministry of Housing and Urban-Rural Development.

Qi, Y., Chan, F. K. S., Thorne, C., O'Donnell, E., Quagliolo, C., Comino, E., et al. (2020). Addressing challenges of urban water management in Chinese Sponge cities via nature-based solutions. Water 12:2788. doi: 10.3390/w12102788

Qiao, X.-J., Liao, K.-H., and Randrup, T. B. (2020). Sustainable stormwater management: a qualitative case study of the Sponge Cities initiative in China. Sustain. Cities Soc. 53:101963. doi: 10.1016/j.scs.2019.101963

Qu, S. Q., and Dumay, J. (2011). The qualitative research interview. Qualit. Res. Account. Manage. 8, 238-264. doi: 10.1108/11766091111162070

Raymond, C. M., Berry, P., Breil, M., Nita, M. R., Kabisch, N., M., Belf, M. d., et al. (2017). An Impact Evaluation Framework to Support Planning and Evaluation of Nature-Based Solutions Projects. Wallingford: C. f. E. Hydrology. Available online at: https://ora.ox.ac.uk/objects/uuid:3ecfc9071971-473a-87f3-63d1204120f0 (accessed December 19, 2020).

Sohu News (2020). The development of PPP in (2020). Available online at: https:// www.sohu.com/a/444669489_120077488 (accessed October 23, 2020).

State Bureau of Surveying and Mapping. (2008). Map Of The People's Republic Of China. Available online at: http://www.chinatouristmaps.com/china-maps/ administrative-divisions/china-political-map.html (accessed April 6, 2018).

Tang, Y. T., Chan, F. K. S., O’Donnell, E. C., Griffiths, J., Lau, L., Higgitt, D. L., and Thorne, C. R. (2018). Aligning ancient and modern approaches to sustainable urban water management in China: Ningbo as a "Blue-Green City" in the "Sponge City" campaign. J. Flood Risk Manag. 11:12451. doi: 10.1111/jfr3.12451

Thorne, C. R., O’Donnell, E. C., and Ozawa, C. P. (2015). Overcoming uncertainty and barriers to adoption of Blue-Green Infrastructure for urban flood risk management. J. Flood Risk Manage. 10, 1-13. doi: 10.1111/jfr3.12218

Wang, H., Mei, C., Liu, J., and Shao, W. (2018). A new strategy for integrated urban water management in China: Sponge city. Sci. China Technol. Sci. 61, 317-329. doi: 10.1007/s11431-017-9170-5

Wenliang, W., Lingwei, Z., Junqi, L., Wei, C., Huiwei, X., Chengjiang, L., et al. (2018). Assessment Standard for Sponge City (GB/T51345-2018). Beijing: Ministry of Housing and Urban-Rural Development.

Wu, Y., Liu, J., Xie, H., Yu, G., Zhou, H., and Yan, Y. (2020). Towards government mechanisms of sponge city construction in China: insights from developed countries. Water Policy 22, 574-590. doi: 10.2166/wp.2020.155

Xia, J., Zhang, Y., Xiong, L., He, S., Wang, L., and Yu, Z. (2017). Opportunities and challenges of the Sponge City construction related to urban water issues in China. Sci. China Earth Sci. 60, 652-658. doi: 10.1007/s11430-016-0111-8

Xiang, C., Liu, J., Shao, W., Mei, C., and Zhou, J. (2019). Sponge city construction in China: policy and implementation experiences. Water Policy 21, 19-37. doi: 10.2166/wp.2018.021

Xiaoping, Y., Dongmei, C., Panagiotis, A., Zonghan, Y., and Tina, B. (2020). Online social networks, media supervision and investment efficiency: an empirical examination of Chinese listed firms. Technol. Forecast. Soc. Chang. 154:119969. doi: 10.1016/j.techfore.2020.119969

Yang, J., Ma, J., Zhang, Y., and Hong, J. (2018). With whom should you have dinner? A multidimensional framework for understanding political ties in China. Business Horizons 61, 891-898. doi: 10.1016/j.bushor.2018. 07.010

Yang, Y., Ling, Z., Yang, Z., Liang, F., Jing, L., Zhiguang, S., et al. (2020). Sponge City Construction Special Planning for Central Area of Guian New District (2016-2030). Gui'an: Gui'an Urban Planning and Construction. 
Yutao, W., Mingxing, S., and Baimin, S. (2017). Public perceptions of and willingness to pay for sponge city initiatives in China. Resour. Conserv. Recycling 122, 11-20. doi: 10.1016/j.resconrec.2017.02.002

Zevenbergen, C., Fu, D., and Pathirana, A. (2018). Transitioning to Sponge cities: challenges and opportunities to address urban water problems in China. Water 10:1230. doi: 10.3390/w10091230

Zhang, L., Sun, X., and Xue, H. (2019). Identifying critical risks in Sponge City PPP projects using DEMATEL method: a case study of China. J. Clean. Product. 226, 949-958. doi: 10.1016/j.jclepro.2019.04.067

Zong, Y., and Chen, X. (2000). The 1998 flood on the Yangtze, China. Natural Hazards 22, 165-184. doi: 10.1023/A:1008119805106

Zongmin, L., Shuyan, X., and Liming, Y. (2018). A systematic literature mining of Sponge City: trends, foci and challenges standing ahead. Sustainability 10:1182. doi: $10.3390 /$ su10041182
Conflict of Interest: JG was employed by National Institute of Water \& Atmospheric Research Ltd (NIWA).

The remaining authors declare that the research was conducted in the absence of any commercial or financial relationships that could be construed as a potential conflict of interest.

Copyright (c) 2021 Qi, Chan, O’Donnell, Feng, Sang, Thorne, Griffiths, Liu, Liu, Zhang, Li and Thadani. This is an open-access article distributed under the terms of the Creative Commons Attribution License (CC BY). The use, distribution or reproduction in other forums is permitted, provided the original author(s) and the copyright owner(s) are credited and that the original publication in this journal is cited, in accordance with accepted academic practice. No use, distribution or reproduction is permitted which does not comply with these terms. 